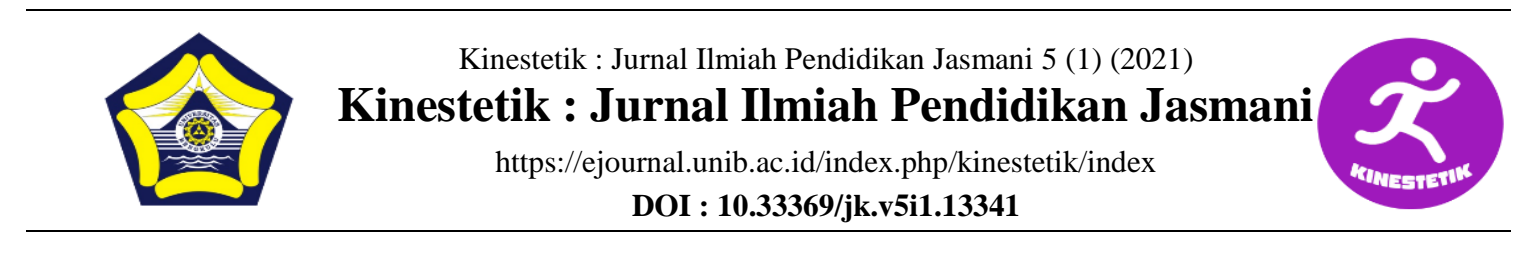

\title{
IMPLEMENTATION OF TRAINING AID TOOLS DEVELOPMENT (REMOTE CONTROL AND HEADSET) FOR SPRINT TUNANETRA ATHLETES
}

\author{
Albadi Sinulingga ${ }^{1 *}$, Novita ${ }^{2}$, Joni Tohap Maruli Nababan ${ }^{3}$ \\ ${ }^{123}$ Sport Science, Universitas Negeri Medan, Medan, Indonesia
}

\section{Article Info}

Article History:

Received : November 2020

Revised : Desember 2020

Accepted : March 2021

Available online : March

2021

Keywords:

Assistive tools, blind sprint athletes

\begin{abstract}
The purpose of this study was to develop training aids (remote control and headset) for sprint athletes with visual impairments as a directional controller during a sprint running exercise program. The benefit of this research is to produce training aids for sprint athletes with visual impairments. This study uses research and development research and development methods. The research was carried out in 2 places, namely the Yapentra SLB-A school for small-scale trials and Karya Murni's SLB-A large-scale trials for the development of blind sprint athletes in North Sumatra NPC. The analysis technique uses quantitative descriptive. The conclusions of this study are: (1) In using remote control and headsets, athletes focus more on personal abilities without thinking about collaboration, acceleration and communication, (2) Using remote control and headsets, athletes are more confident and more independent in sprinting activities. Using remote control and headsets, guades and coaches are more focused in conveying information and are more efficient in training blind athletes with sprint running numbers by looking at personal abilities and motivation as sprint athletes running norms.
\end{abstract}

Corresponding address: Jl. William Iskandar Ps. V, Kenangan Baru,

Kec. Percut Sei Tuan, Sumatera Utara

*Email: badisling@hotmail.com
ISSN 2685-6514 (Online)

ISSN 2477-331X (Print) 


\section{INTRODUCTION}

Disability sport was started by Sir Ludwig Guttmann holding a sporting event in 1948 known as the Stoke Mandeville (the first Paralympic Games). The first Olympic games for athletes were held in Rome in 1960, they are considered to be the first Paralympics. In Asia, the emergence of the FESPIC Game (Fat East and South Pacific Games for the Disabled), a multi-sport event for athletes with disabilities was first held in 1975 in Oita.

Disability is closely related to both physical and mental health. Many disabilities have a background of health problems, and conversely, disability conditions can also affect health. The health sector plays a role in prevention to rehabilitation efforts. For example, people with disabilities need to get special and affordable services according to the needs of their disabled persons as discussed in the "Workshop on terminology of persons with disabilities in order to encourage the ratification of international conventions on the rights of persons with disabilities" held in 2009.

Dwi Gansa, et al (2016) argued that people with disabilities have long-term physical, mental, intellectual, or sensory limitations, where when faced with various obstacles, this can make it difficult to fully and effectively participate in society based on equal rights.

As stated in the UN Convention on the Rights of Persons with Disabilities signed in Indonesia on March 30, 2007 in (Irwanto et al, 2010) states "Recognizing that disability is an evolving concept and that disability results from the interaction between persons with impairments and attitudinal and environmental barriers that hinders their full and effective participation insociety on an equal basis with others ". Means "disability" is a pattern of describing the results of interactions between individuals with physical or mental / intellectual disabilities with attitudes and the environment inhibiting their ability to participate in society fully and equally with other people, analyzed more broadly by (Irwanto et al, 2010).

Disability is defined where functional limitation and / or impairment is a causative factor, and an existing difficulty in performing one or more activities which, in accordance with the person'sage, sex, and normative social role, are generally accepted asessential, basic components of dailyliving, such as selfcare, social and economic activity. Depending in part on the duration of the functional limitation, disability may be short term, longterm or permanent disability will be dealt.

Furthermore, disability in Indonesia is regulated in Law of the Republic of Indonesia Number 19 of 2011 concerning Ratification of the Convention on the Rights of Persons with Disabilities (the Convention on the Rights of Persons with Disabilities) no longer uses the term disabled, replaced by persons with disabilities, (Dwi Gansar et al. 2016). Around the 1990s, in Indonesia the term 'diffable', which stands for 'differently abled', appeared in Indonesia as a counter to the use of the term people with disabilities that were considered and deemed stigmatic (Suharto, 2011).The 
term persons with disabilities is replaced by the term persons with disabilities because the term contains values which tend to form negative meanings. This term is used with the argument that they are not incapable as a translation of disability, but have different abilities (Dini Widinarsih, 2019).

In essence, disability is difficulty in carrying out daily activities and they get personal, social, economic, ability and responsibility assistance that should be ignored. Sports for people with disabilities are used as a medium to develop their potential and talents, considering that every human being apart from having weaknesses also has its own advantages, abilities and uniqueness (Dwi Gansa, et al, 2016). Sports activities do not require many requirements and everyone has the right to participate, including people with disabilities.

In Indonesia, sports with disabilities The development and development of sports for persons with disabilities is protected by law as stated in Law no. 3/2005 on SKN Article 6, namely: (1) Sports fostering and development for persons with disabilities is carried out and directed to improve health, selfconfidence and sports achievement; (2) Sports fostering and development of persons with disabilities is carried out by sports organizations of persons with disabilities through upgrading and training activities as well as tiered and sustainable competence at regional, national and international levels; (3) Relevant agencies, regional governments, and / or sports organizations for persons with disabilities in society are obliged to form a center for fostering and developing sports specifically for persons with disabilities;

Results of observations (interviews, questionnaires, videos) to the Management, Trainers, Guides, Athletes, carried out on Tuesday, March 13 2018, Suliadi (North Sumatra NPC Management) stated that the North Sumatra NPC (National Paralympic Committee) had fostered eight sports, namely: athletics, chess, weight lifting, judo, table tennis, swimming, goal-ball and badminton. The addition of new sports to the (National Paralympic Committee) has long been planned.

The results of observations made by Deputy Secretary Suliadi (National Paralympic Committee) of North Sumatra stated that until now (National Paralympic Committee) Medan City has produced many athletes with visual impairments at the regional, national level, while sports for blind people have been fostered and developed by (National Paralympic Committee) includes athletics, chess, table tennis, swimming, weight lifting, goal-ball.

Since the beginning of 2015 , he became a committee in North Sumatra, until 2018 nearly 200 athletes were registered in North Sumatra, especially for active blind athletes trained / fostered by 2 (two) men and women in the 100 meter branch, there are also chess, swimming, and goal-ball. For the achievements of Indonesia at the Asian Para Games, 42 Asian countries participated in 18 sports, nearly 2800 Indonesian athletes ranked 4th (fourth) after China, Japan, Korea. This achievement is quite encouraging compared to the 2014 Asian Para Games, 
Indonesia is in 9th place. (Nine). At the Asian Para Games, North Sumatra sent 17 athletes, of which 10 athletes won medals, 6 (six) gold, 2 (two) silver, 10 bronze. Even so, North Sumatra has learned a lot from this.

Considering that there are many tasks that must be completed in the future, in particular the guidance and training carried out are far behind other countries (China, Japan, Korea). Where countries (China, Japan, Korea) in training coaching have developed equipment to use technology so that training coaching, programs, evaluations, etc., can be detailed quickly, accurately and precisely. It has been left behind in training guidance especially in North Sumatra Province.

In Indonesia, the development of blind athletes' equipment is still underdeveloped, perhaps because our country does not have sufficiently sophisticated technology and sports experts do not collaborate with technology experts. This is evident during the training and events of the National Championship (Kejurnas), NPC (National Paralympic Committee) in Bandung, West Java, where tools and assistance are carried out, as well as exercises carried out in Medan, generally still manual.

In accordance with the facts on the background above, communication is one of the most common problems, with remote control and communication headsets standardized so that athletes can easily remember and respond to existing information, making it easier for athletes to make decisions. The researcher's offer made a solution, namely developing a tool to overcome the problems experienced by blind athletes in the 100 meter sprint sport. In this study, researchers developed training aids (remote control and headset) for sprint athletes with visual impairments.

Borg and Gall (1983) stated that research and development is a process used to develop or validate products used in education and learning.

The Research and Development method which is commonly abbreviated (R\&D) has the same meaning as development research. According to Borg and Gall (Saputro, 2017). Development is an attempt to make tools (instruments) that are used to gather information related to basic skills. Development is directed at instruments that are expected to provide useful contributions for users or prospective teachers. An instrument is something that can be used to make it easier for someone to do a task or achieve a goal effectively or efficiently. Instruments are also called tools (Arikunto, 2010). Development is defined as a process to expand and deepen existing knowledge Antonio, Sabaruddin Yunis (2019) development is a process of renewal from the previous one, it can be translated into physical form by applying technology, both in the form of printed technology, audio-visual technology, and integrated technology to produce products.

In this study, researchers developed training aids (remote control and headset) for sprint athletes with visual impairments to control the direction when doing a sprint running exercise program.Law Number 8 Year 2016 Concerning Persons with (Disabilities, 2016) Tools is an object that functions to help Persons with 
Disabilities to be independent in carrying out their daily activities.

Blindness is basically a condition of the eye or visual field which for some reason does not function properly, so that it experiences limitations and or the inability to see. In this case, tuna means wounded, damaged, lacking or missing. Visually impaired means the eye or the sense of sight (Sari Rudiyati, 2002).

IAAF (2001) "Level I-II for event sprint", Spint (speed) is the ability to perform movements with a short time / short. The speed of sprinting is generally very much influenced by two factors, namely the frequency of steps and the length of the stride.

The purpose of this study was to develop training aids (remote control and headset) for sprint athletes with visual impairments as a directional controller when doing a sprint running exercise program. The benefit of this research is to produce training aids for blind sprint athletes, as a cruel basis for the government (Dispora, KONI, NPC, SLB School) in the use of science and technology for blind sprint athletes (National Paralympic Committee). As input for administrators and blind coaches in the use of science and technology for blind sprint athletes (National Paralympic Committee).

\section{METHODS}

\section{Research Methods}

This study uses research and development methods. Research and development is a research method used to produce certain products, and to test the effectiveness of these products.
To be able to produce certain products used research that is needs analysis and to test the effectiveness of these products so that they can function in the wider community, research is needed to test the effectiveness of these products (Sugiyono, 2017).

The research was carried out in 2 places, namely the Yapentra SLB-A school for small-scale trials and Karya Murni's SLB-A large-scale trials for the development of blind sprint athletes in North Sumatra NPC.

The research procedure for developing training aids (remote control and headset) in blind sprint athletes adapting the steps (Sugiyono, 2017).

The analysis used is descriptive analysis with the aim of knowing the athlete's needs or a guide to the obstacles faced during the training process. Then the formula (Sudjana, 2013). The questionnaire results were analyzed using the following criteria.

Table 1. Likert Scale Category

\begin{tabular}{cccc}
\hline \multicolumn{2}{c}{ Positive } & \multicolumn{2}{c}{ Negative } \\
\hline Assessment & Score & Assessment & Score \\
\hline $\begin{array}{c}\text { Strongly } \\
\text { agree }\end{array}$ & 5 & $\begin{array}{c}\text { Strongly } \\
\text { agree }\end{array}$ & 1 \\
\hline Agree & 4 & Agree & 2 \\
\hline Doubtful & 3 & Doubtful & 3 \\
\hline Disagree & 2 & Disagree & 4 \\
\hline $\begin{array}{c}\text { Strongly } \\
\text { disagree }\end{array}$ & 1 & $\begin{array}{c}\text { Strongly } \\
\text { disagree }\end{array}$ & 5 \\
\hline
\end{tabular}

The data obtained through a questionnaire were then tested using the percentage test.

The collected data were analyzed by using quantitative descriptive analysis techniques which were expressed in the distribution of scores and percentages 
against predetermined rating scale categories. After presenting in percentage form, the next step is to describe and draw conclusions about each indicator. The suitability of aspects in the development of media tools can use the following table:

Table 2. Category Percentage, Suharsimi

\begin{tabular}{cc}
\hline $\begin{array}{c}\text { Percentage of } \\
\text { Achievement }\end{array}$ & Interpretation \\
\hline $\mathbf{7 6 - 1 0 0 \%}$ & Well worth it \\
\hline $\mathbf{5 6 - 7 5 \%}$ & Decent enough \\
\hline $\mathbf{4 0 - 5 5 \%}$ & Not worth it \\
\hline $\mathbf{0 - 3 9 \%}$ & Not feasible \\
\hline
\end{tabular}

\section{RESULT}

\section{Potential Problems}

Results of observations (Interviews, Questionnaires, Videos) to Managers, Coaches, Guides, Athletes, which were carried out on Tuesday, March 13 2018, Suliadi (North Sumatra Management) stated (National Paralympic Committee) North Sumatra has fostered eight sports, namely: athletics, chess, weight lifting, judo, table tennis, swimming, goal ball and badminton. addition of new sports in (National Paralympic Committee) Based on the facts of interviews, observations and questionnaires by administrators, coaches, guides, research athletes are interested in contributing ideas to the problems of blind sprint athletes.

\section{Data collection}

From the needs analysis that has been carried out on 10 blind people, it is found that $90 \%$ have competed in blind sprint matches, $90 \%$ of them have problems during sprint training, $90 \%$ of them they have the same problems during training, $80 \%$ of them have never received help handling technology. $100 \%$ they want them to have some tools to overcome the obstacles they experience during training. The analysis used is descriptive analysis with the aim of knowing the athlete's needs or a guide to the obstacles faced during the training process. Based on the results of observations, interviews and needs analysis above, it can be concluded that administrators, coaches / guides especially athletes are eager to get training aids (remote control and heatset).

This research is to develop training aids for blind athletes with remote control and headsets that can be used as a means of athletic training. This development will support performance sports specifically in the sprind branch for blind athletes. The products in this research and development attempt to make remote control devices and headsets using technological media, besides that they can also be used for other athletic sports related to motion control in other athletic branches. Then this product is expected to be the latest innovation for directional control that is more effective and efficient when used for training and competition, and can be used as a solution to problems in the training and competition process.

Before testing the initial product, product validation was carried out on sports experts, trainers, IT / Technology experts.

The first test is carried out after the initial product or the development of training aids (remote control and headset) has been observed, corrected and declared 
worthy of testing by experts. The first test consists of 9 (nine) experts, namely 3 sports experts, 3 trainers, 3 IT / Technology experts. The results of evaluations carried out by experts refer to indicators that have been prepared previously, which become a reference to test whether the product is suitable for use or not.

From the results of discussions and questionnaires given to 3 (three) Experts, namely Sports experts, IT / Electrical Experts, Expert Trainers focusing on product usage procedures, the expert stated that the development of training aids (Remote Control and Headset) products for blind sprint athletes is feasible to be used or worthy to be tested.

During the implementation of field trials, researchers made intensive observations and recorded important things that were done by respondents that would be used as materials for the improvement of the initial product. Before the trial was carried out, the researcher socialized how to use the remote control device, after all understood the operation of the tool, then the trial was carried out.

During the implementation of field trials, researchers made intensive observations and recorded important things that were done by respondents that would be used as materials for the improvement of the initial product. Before the trial was carried out, the researcher socialized how to use the remote control device, after all understood the operation of the tool, then the trial was carried out.

From the results of small group trials and guides after sprinting using a remote control and headset, athletes and guides were given a questionnaire to fill in according to their own understanding. Blind athletes filled out a questionnaire assisted by the research team. From the results of small trials on 10 blind athletes and 5 guides / coaches, it was concluded that the development of training aids (remote control and headsets) for blind sprint athletes fulfills the criteria to be continued in large group trials because the percentage of each aspect is $85 \%-98 \%$.

\section{Product Revisions}

The initial product refinement will be carried out after a limited field trial is carried out. At this initial product refinement stage, most of the time it is done with a qualitative approach. The evaluation is more on the evaluation of the process, so that the improvements made are internal improvements. In improving the initial product, pay attention to and take into account the results of the recollection of the questionnaire given to athletes and guides / coaches during the small group test, starting from the aspect of effectiveness to the design, the product revisions are made to take into account the suggestions given by athletes and guides.

The modified product components are as follows:

1. Minimizing the components of the Transmitter and Receiver.

2. Adding antenna components.

3. The hook is refined to make it more efficient.

4. The voice code is emphasized and standardized.

The product developed in this floating research is a directional control device that uses technological media. 
The product in this development research has created a remote control device for blind athletes using technology media, which can work effectively and efficiently so that it can attract athletes.The things that are revised from the results of interviews, questionnaires, and observations during the trial are as follows:

1. The buttons have different colors.

2. Minimizing size.

3. A headset that is adapted to the shape of the ear curve.

revisions and improvements do not reduce the original function but improve and improve product quality. For approximately 14 days the data processing and repair of the tools were carried out. Before carrying out a wider field trial / final product trial, the product that has been repaired is validated by experts.

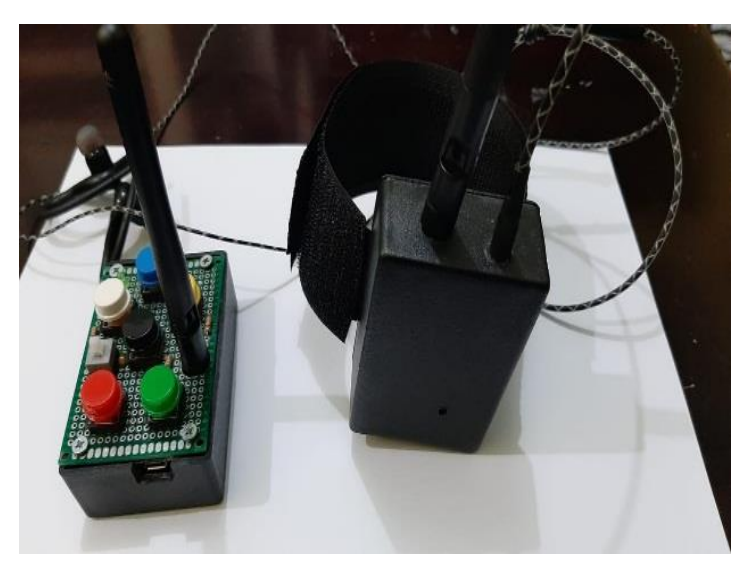

Figure 1. Remote Control and Headset Tool Test Results, Expert Revision, and Validation

\section{CONCLUSION}

The conclusions of this study are: (1) In using remote control and headsets, athletes focus more on personal abilities without thinking about collaboration, acceleration and communication, (2)
Using remote control and headsets, athletes are more confident and more independent in doing sprint running activities. . Using remote control and headsets, guades and coaches are more focused in conveying information and are more efficient in training blind athletes with sprint running numbers by looking at personal abilities and motivations as sprint athletes running norms.

\section{REFERENCES}

Andajani, S. J., \& Oce Wirawan, P. (2020). Development of Detector Vibrating Watch Model for 100-Meter Dash Race for Visually-impaired Athletes. International Journal of Online \& Biomedical Engineering, 16(10).

Anthonio, Sabaruddin Yunis Bangun. (2019). Development of Learning Pocket Books Pencak Silat Extracurricular as Junior High School Learning Resources. 1st Unimed International Conference on Sport Science (UnICoSS 2019). Advances in Health Sciences Research, volumes 23 (143-147).

Dini Widinarsih. (2019). Persons with Disabilities in Indonesia: Developments in Terms and Definitions. Journal of Social Welfare Science, Vol. 20.No: 2, 127-142

Du, J., Shi, Y., Zou, Z., \& Zhao, D. (2018). CoVR: Cloud-based multiuser virtual reality headset system for project communication of remote users. Journal of Construction Engineering and Management, 144(2), 04017109.

Dwi Gansar. (2016). Sports Coaching for Persons with Disabilities in the Salatiga National Paralympic Committee. Journal of Physical Education and Sport. Vol. 5. No: 1, 17-23. 
Hakim, A. R. (2017). Memuliakan Anak

Berkebutuhan Khusus Melalui Pendidikan Jasmani Adaptif. Jurnal Ilmiah Penjas (Penelitian, Pendidikan Dan Pengajaran), 3(1).

Irwanto et al (2010). Analysis of the Situation of Persons with Disabilities in Indonesia. Jakarta: Center for Disability Studies, Faculty of Social and Political Sciences, University of Indonesia.

Nababan, J. T. M., \& Sinulingga, A. (2020, March). Development of Training Aids (Remote Control and Headset) for Tunanetra Sprint Athletes. In 1st Unimed International Conference on Sport Science (UnICoSS 2019) (pp. 160-163). Atlantis Press.

Republic of Indonesia. (2016). Article 1 Number 10 Law Number 8 Year 2016 Concerning Persons with Disabilities.

Saputro, B. (2017). Development research management. Yogyakarta: Aswaja Pressindo

Sudjana, Nana. (2013). Basics of Teaching and Learning Process. Bandung: Sinar Baru Algensindo.

Sugiyono. (2012). Business Research Methods. Bandung: Alfabeta.

Sugiyono. (2017). Quantitative, Qualitative, and $\mathrm{R} \& \mathrm{D}$ Research Methods. Bandung: Alfabeta, CV.

Suharsimi Arikunto. (2010). Research Procedure. Yogyakarta: Rineka Cipta.

Suharto, S. (2011). Difability and community based empowerment. Lessons from the translation of the Right to work of People with impairments in Indonesia. Saarbrucken, Germany: VDM Verlag Dr. Muller GmbH \& Co.KG. 